\title{
The Self/Other Representation in Western Media : A Socio- Cognitive Approach
}

\author{
Shaimaa Shaban Abdullah Hussein
}

Fayoum University

\section{7}

\begin{abstract}
The purpose of this paper is to analyze the self/other representation in news media. Media discourse helps to produce and reproduce stereotypes about the other to serve the favor of the dominant groups. Therefore, this paper attempts to uncover the bias and stereotypes against the other. To achieve this objective, the data for the analysis is gathered from three different newspapers: The New York Times, The Guardian and The Washington Post. The researcher analyzes the headlines and lead paragraphs taken from these newspapers based on Van Dijk's (1998) Socio-Cognitive approach. The findings revealed that the 'self' is represented positively while the 'other' is presented negatively in news texts. This positive selfrepresentation vs. the negative other representation is ideologically based to serve the interests of the dominant groups.
\end{abstract}

Keywords: ideologies, stereotypes, framing,power 


\section{Introduction}

Media discourse constructs certain negative images about the other. According to Montgomery (2007), news media "constructs the world in such a way as to conform to an image shaped by partial interests typically those of the powerful" (p.21). This misrepresentation is ideologically significant. It works for the best interests of the dominant groups. By presenting the "other" in an unfavorable light, the dominant groups can enforce their ideologies and power. Meanwhile, the 'self' is presented positively. This positive self representation vs. the negative other representation has an ideological function. It helps to highlight the positive acts of the dominant groups while emphasizing the negative acts of the other. In doing so, the dominant groups can legitimatize the self while delegitimizing the other. For example; the war against Iraq was legitimatized by Bush administration as brining democracy to the country and freeing the Iraqis from a dictator(ElTantawy 2007).Therefore, it is crucial to unmask the ideologies behind the binary representation of the self/other.

Moreover, news media tend to frame the other in order to support the ideologies of the dominant groups .Framing constructs people's perception towards certain issues. Chong and Druckman (2007) state, "Framing refers to the process by 
which people develop a particular conceptualization of an issue or reorient their thinking about an issue" (p.104). In their representation of the "other", journalists rely on frames as they are ready made schemata that label the other in negative terms. Frames then construct stereotypes about the other. Hence, news media is biased as they represent news from one side that is the dominant groups.

Accordingly, it is becoming crucial to highlight the bias in the negative representation of the other. To achieve this objective, the researcher applies Van Dijk's(1998) sociocognitive approach that is characterized by a binary opposition in the positive self-representation and the negative other. With this approach being applied to media studies, the readers can be made aware of the existence of ideologies in the positive representation of the self and the negative representations of the other.

\subsection{Objectives of the Study}

This study attempts to investigate the following points:

a) How the self/other is represented in Western media.

b) The hidden ideology behind this representation.

c) The role of the media in perpetuating stereotypes about the other groups.

\subsection{The Conceptof "Us" vs. "Them"}


One of the effective discourse practices is the use of the pronominal pair "US' vs "Them through which the speaker draws social boundaries or polarization between the in-group and the out-group (Van Dijk, 2000). This binary opposition benefits the interests of the dominant groups. For instance, after 11 Sept attack and in an attempt to legitimate the war against Iraq and to mobilize the public against Muslims, Bush said 'eitheryou're with us or with the terrorists'. By doing so, he divided the world into two parts: "Us" and "the terrorists" instead of "us" and "them". The ideology here is to mobilize America and the rest of the world against "a common enemy" (Davies, 2007, p.71). Therefore, Van Dijk's ideological square is employed in this study to highlight the subtle uses of 'US' vs. "Them".

Aside from using the binary 'US' vs. 'Them' to represent the 'in-groups' positively and the 'out-groups' negatively, it is also employed to legitimatize the in-group while delegitimize the out-group. In a study by Irham\& Wahyudi (2012) on Netanyahu's peacemaking speech at UNGA 2011, they illustrated that Israelis (the in-group) are represented in a positive way while the Palestinians (the out-group) are represented negatively. This polarization is done to legitimatize the Israelis while delegitimize the Palestinians (Van Dijk, 2000). 
Another use for this binary 'Us' and 'Them' is to dehumanize the enemy. For example, in Steuter and Willis' (2009) study of Canadian news coverage of the war in Afghanistan and Iraq, the study revealed "a pattern of dehumanizing language applied to enemy leaders as well as Arab and Muslim citizens" besides the use of "animal imagery that reduced human actions with sub-human behaviors"(p.1). This imagery is produced and reproduced in media to create negative stereotypes of the 'Others' which in turn serve the favor and the ideologies of the dominant groups. It is in the best interest of the powerful groups to represent the 'Other' groups negatively in order to delegitimize them.

In brief, the concept of "Us" vs. "Them" could be used to represent the self in a favorable light, legitimatize the self and dehumanize the enemy or the other. This discursive practice is employed in discourse to serve the favors of the dominant groups. Therefore, it is highly important to highlight such usage of biased representation in order to challenge it.

\section{Review of literature}

A great number of researchers approached the self and other representation in news discourse (Merskin (2004);KhosraviNik (2009); Rashidi\&Souzandehfar(2010); Pasha (2011); Irham\&Wahyudi (2012),...etc.). All of these 
studies contributed to the understanding of the self vs. the other representation in media discourse. Therefore, it is important to review them in order to unmask the ideologies behind such representation.

First, Merskin (2004) analyzed Bush's speeches after 11 Sept attacks. The study used Spillman and Spillman's (1997) model of enemy image construction as a framework for data analysis. This model chronologically traces the development of Arab enemy image in Bush's rhetoric. The analysis revealed that there are derogating terms and images that serve to 'dehumanize' the other and make any backlash against Arabs and Muslims appear natural and logical. This image resulted in the mental image construction of "all Arabs as Muslims and All Muslims as terrorists" (Merskin, 2004, p.158). For example, after 11 Sept attack, American film industry depicted Arabs in images associated with 'barbarism' and 'cruelty'. The study concluded that this enemy image of Arabs and Muslims reinforced the ideological dichotomy of good vs. evil and 'us' vs. 'them'.

Moreover, KhosraviNik (2009)studied the way refugees and immigrants were represented in the British newspapers in the period between 1996-2006. This period covered important world events that affected the representation of these groups. 
The study used CDA as an approach to the linguistic choices used by the British newspapers at that time. It also combined both the qualitative and quantitative methods for the data analysis. The data analysis found out that refugees and immigrants were represented in a negative way influenced by the ideological stands of the newspapers. Further analysis indicated that there was a very sharp distinction between "Us" vs. 'them'. This differentiation strategy accounts for the negative perception of them as the illegitimate "other".

Furthermore, Rashidi\&Souzandehfar(2010) examined the underlying ideologies in the US Democratic and the Republican presidential candidates of 2008 over the issue of the continuation of the war in Iraq by using CDA. They adopted Van Dijk's (2004) framework of 'Self'vs. the 'Other' representation. The study found out that lexicalization, polarization, and rhetoric were effective persuasion devices in the legitimization of the war by the Republican candidates. Meanwhile, the Democratic candidates delegitimized the continuation of the war in Iraq. The results showed that there was a hidden ideology in the candidates discourse.

Besides, Pasha (2011) studied the Egyptian ideology using Van Dijk's ideological square which is characterized by a positive self-representation and a negative other representation. 
For example, the Muslim brotherhood was depicted as "unofficial" presenting them as an illegitimate group. Therefore, any activities conducted by this group would be considered illegal. The study also explored how Islamists were socially and discursively depicted in Egyptian newspapers. The study illustrated that the 'Other' was represented in a negative image as Van Dijk's ideological square of 'we' are good and 'they' are bad was a recurrent image all over the news reports. Finally, the study concluded that the Egyptian regime has been exercising constant power towards Muslim Brotherhood through the constant negative representation of them as 'bad' and a "threat". This negative image led to the stereotypes that all Muslim Brothers are bad and hence they are 'unofficial'.

In addition, Irham\&Wahyudi (2012) investigated the 'self' and 'other' presentation in Netanyahu's peace agreement speech at the United Nations General Assembly (2011) by identifying the 'disclaimer' strategy in the speech. Disclaimers arediscursive strategies in which the speaker presents something positive and then rejects it with a particular term such as 'but' (Van Dijk, 2003). Disclaimers also function to legitimatize the in-group and delegitimize the out-group (Van Dijk, 1995a).The study scrutinized thedelegitmation of the other (the Palestinians) by employing CDA. It also examined the macro and micro rules 
in discourse to investigate how discourse could be used to exercise the ideology of the powerful groups. The study found out that Netanyahu employed the disclaimer 'but' as a discursive tool to present his political stance in a positive way while downgrading the 'Other' group.

\section{Theoretical Framework}

\subsection{VanDijk's Socio-Cognitive Approach}

Van Dijk\&Kintsch (1983) examined the relationship between discourse and language processing. They studied how individuals process information in media discourse. Their study was developed into a cognitive model that showed how meaning is constructed in society(Wodak\& Van Dijk 2000). Cognitive models refer to the mental representations, beliefs, and opinions shared by social group members. For instance, racist groups share common propositions and beliefs that organize their structure. Through a constant processing of social cognition, ideologies are produced and reproduced in discourse till they become a system of shared concepts and beliefs upon which social groups define themselves and the others. These ideologies control the minds of the social groups that share the same beliefs and opinions. 
Moreover, ideologies control text and talk via shared cognitive model or representation that determines a group's certain attitude towards social practices. For instance, if social group members share a certain attitude towards certain social issues such as racism, they form a shared mental representation or a model that shapes their attitudes towards these social practices. These shared attitudes, or models, form the basis of everyday practices. Therefore, models have underlying ideologies within them. These ideologies are not clearly explicit in discourse. They are the subjective mental constructs which underlie everyday text and talk, and feature the past, present and future events. In this sense, ideologies not only form the basis of interpretation for past and present actions, but the interpretation of future actions as well.

Since ideologies can interpret the future actions of certain social groups, they build stereotypes about the members of the social groups. These stereotypes are used to account for the other group's negative acts. Therefore, Van Dijk (1995a) indicated that ideologies form subjective mental stereotypes that explain "why people may have biased, wrong, fictitious or misguided representations of reality, as is also clear in, for example, racist representations of ethnic events" (p.252). Accordingly, people share common beliefs and opinions 
towards a social group that make them form certain cognitive models about these groups. These cognitive models are the underlying ideologies that govern group members.

To uncover the hidden ideologies within discourse, Van Dijk (1998) designed a theoretical framework within CDA that is used to systematically analyze ideologies within discourse. This socio-cognitive approach is based on the assumption that the comprehension of news relies on two factors: "society" and "discourse". Van Dijk (1998) explained that "it is only the integration of these accounts that may reach descriptive, explanatory and especially critical adequacy in the study of social problems" (p.98). He argued that any social group has its certain ideology that governs its discourse. In other words, any discourse is ideologically structured. Van Dijk (1998) summarized ideologies as follows:

Ideologies are basic frameworks of social cognitive, shared by members of social groups, constituted by relevant selections of socio cultural values, and organized by an ideological schema that represents the selfdefinition of a group. Besides, their social function of sustaining the interests of groups, ideologies have the cognitive function of organizing the social representations (altitudes, knowledge) of the group, and thus indirectly 
monitor the group-related social practices, and hence also the text and talk of members. (p.248)

To sum up, Van Dijk's socio cognitive approach has significantly contributed to the analysis of media texts. The shared cognitive models are produced and reproduced in media texts. According to Van Dijk (1985), both the production and perception of texts are based on cognitive models or schemata which are shared knowledge, beliefs, and attitudes in society. These schemata are what Van Dijk labels "ideologies". These schemata link society and text, on one hand, and discourse structure and social structure, on the other. Media discourse plays an important role in the production of these cognitive schemata. Hence, news texts are not purely objective. However, they are to some extent biased and based on the ideologies of news reporters.

\subsubsection{Van Dijk's Ideological Square}

Van Dijk(1998) suggested a theoretical framework within CDA that is used to analyze ideologies within discourse. This framework is defined as group self schema. In this model, the in-group is represented positively in news discourse while the out-group is depicted negatively. This strategy of positive "Self" representation vs. the negative "Other" representation, as Kuo\& Nakamura (2005) indicate, consists of "deemphasizing the bad 
property/actions, mitigating our bad properties/ actions and mitigating their good properties/ action" (p.410). The positive acts of the dominant groups are emphasized while mitigating the good actions of the minority groups and vice versa. Similarly, Van Dijk's ideological square (2000) proposed four principles which exist in ideologies and which enable the powerful groups to express subtle ideological stances. They are: “a) Emphasize positive things about Us; b) Emphasize negative things about Them; c) De-emphasize negative things about Us; D) Deemphasize positive things about Them" (Van Dijk, 2000, p.44).These four principles are basic strategies in the self "positive' representation and "negative" other. The theory proclaims that all positive actions are associated with "Us" while mitigating the positive actions of the "Others". On the other hand, no negative sayings should be directed to "Us" meanwhile highlight the negative actions of "Them" (Van Dijk, 2000). This indicates that "us" is always represented in a positive way while "them" is referred to negatively.

This polarized structure of emphasizing the good qualities of the in-group while problematizing the acts of the out-group creates a more polarized structure in discourse. This binary representation tends to favor the in-group and derogates the outgroup. Thus, this positive "Self" representation and the negative 
"Other" representation reflects the ideological structure of discourse. The "We" group is presented favorably while "They" group unfavorably (Kuo\& Nakamura, 2005). This "in-group" vs. the "out-group" description is apparent in the lexical choices and other linguistic features. This polarization of the "Self" vs. the 'Other' in media is based on the following discursive practices (adopted from Van Dijk, 1995a, p. 144):

TABLE 1: Linguistic tools that polarize the in-group vs. the outgroup

\begin{tabular}{|l|l|}
\hline In-group & Out-group \\
\hline Emphasis & De-emphasis \\
\hline Assertion & Denial \\
\hline Hyperbole & Understatement \\
\hline Topicalization & De-topicalization \\
\hline Sentential (micro) & Textual (macro) \\
\hline High prominent position & Low non-prominent position \\
\hline Headline, summarizing & Marginalization \\
\hline Detailed description & Vague, overall description \\
\hline Attribution to personality & Attribution to context \\
\hline
\end{tabular}




\begin{tabular}{|l|l|}
\hline Explicit & Implicit \\
\hline Direct & Indirect \\
\hline Narrative illustration & No stereotyping \\
\hline Argumentative support & No argumentative support \\
\hline Impression management & No impression management \\
\hline
\end{tabular}

Accordingly, these discursive practices of the 'Self' vs. the 'Other' representation are used to uncover ideologies within discourse. Through using his ideological framework, Van Dijk (1998) analyzed news in terms of two levels: Macro rules and news schemata. First,the macro rules refer to the "macro propositions" within the news stories or ideologies. News discourse is structured around three macro rules: deletion of information, generalization and construction. Deletion of information means downplaying any information that describes the negative acts of the dominant groups or not mentioning sufficient details about them. Second,news schemata then go through along process of selection and production. Selecting what is newsworthy and what is not makes news reporting biased as this process of selection does not cover all sides of the story but instead chooses some aspects over others. Production of news also leads to bias in news reporting in the sense that 
news is influenced by the ideology of the journalists. In other words, journalists tend to report news from their own ideological stance which makes news production biased and subjective.

\section{Methodology}

\subsection{Methods \& procedures}

This study investigates the Self/Other representation in news media. The data for analysis is gathered from three Western newspapers: The New York Times, The Washington Post and The Guardian. The reason for choosing these three newspapers is that they are loaded with discursive practices that serve the objectives of this study. The researcher examines the headlines and lead paragraphs of these newspapers. The collected data are analyzed in terms of Van Dijk's (1998) ideological square. This framework is commonly used in the analysis of news discourse as it can unmask the underlying ideologies within it.

\section{Data Analysis}

The data is analyzed on the macro structure of discourse by using Van Dijk's ideological square.Van Dijk (1998) noticed that group members use positive "Self' representation to accentuate their beliefs, values and achievements and negative 
'Other' representation or misrepresentation of values, beliefs and actions in order to overpower them. According to Van Dijk (1993a), "the justification of inequality involves two complimentary strategies, namely the positive representation of the own group, and the negative representation of the others" (p.263). Hence, this framework explores the underlying ideologies in the representation of the "Self" vs. the other.

\subsection{Application of Van Dijk's Ideological Square}

\subsubsection{The positive "Self" representation}

According to Van Dijk's ideological frame, the bad actions of "the 'Other' are being emphasized and given prominence while the negative acts of the 'in-group' are deemphasized and mitigated. The concept of "we" are good and "they" are bad is clearly apparent in the following headlines:

1-In the aftermath of these hate-filled events, there is a chance to stand against terror without employing terror (11 Jan, The Guardian)

2-CHARLIE HEBDO: In their words and works, American cartoonists condemn Wednesday's attack, hail slain satirists as 'heroes' (By Michael Cavna, January 8, 2015, The Washington Post) 
Example (1) indicates that "we" are good as "we" will fight terror acts without using any violence. In example (2) the "Self" is represented positively as "heroes" victimized by the other's terror act. Indeed, the author seeks to draw the reader's sympathy towards the victims of the in-group and to represent the "Other" group as terrorists. This labeling accentuates the negative acts of the "Other" as it draws on a stereotypical image of Muslims as "terrorists".

\subsubsection{The Negative 'Other' representation}

According to Van Dijk, the negative acts of the 'Other' group are pointed out and stressed. Besides, the Other's action is described implicitly in strong negative words (such as cowardly, cruel, dismay, inhumanity, etc.) regardless of the motive. This negative description of the "Other" is ideologically driven as to disfigure the image of Muslims and to represent the dead people in Charlie Hebdo; the French magazine that was attacked for publishing abusing cartoons for Prophet Muhammad, as innocent victims of Islamist terror attack. This positive 'self' representation vs. negative 'other' representation serves the interests of the dominant group. The following lead paragraphs taken from Op-ed articles illustrate this negative "Other" representation: 
1- Last week's attack on Charlie Hebdo magazine in Paris and the subsequent, linked hostage-taking at a Jewish supermarket were appalling acts of inhumanity that should be universally condemned. (11 Jan, 2015,The Guardian)

2- Attack on Charlie Hebdo was a direct assault on freedom of speech(Jan 7,2015, The New York Times)

3- Can violence be moral?(by David Nussbaumand Séamus A Power,28 Feb, The Guardian)

4- The Charlie HebdoMassacre in Paris (By the Editorial Board, Jan7, 2015, The New York Times.

5- Obama condemns 'terrible terrorist attack' in Paris (By Katie Zezima,7Jan,2015, The Guardian)

Clearly, example (1) generalizes the Other's act as an aggressive attack on 'humanity' while depicting the "Self" as victims of this horrible attack. Indeed, this negative representation of the 'other' is ideologically driven. By employing this generalization technique, the journalist is attempting to mobilize the world against Islam. Example (2) represents the Other's act as a violent act against what is allegedly called "freedom of expression". The assumption being made here is that anyone is free to express his/her opinions even 
if they were religiously abusing. Those who counteract this alleged "freedom of speech" are considered "extremists". Example (3) describes the Other's act as "unethical" or "immoral "but it does not consider the publication of the sarcastic cartoons 'immoral' or 'offensive'. Obviously, the negative acts of the in-group are deemphasized and mitigated. In other words, the Self's "immoral" actions of drawing the religiously abusing cartoons is being back grounded or deemphasized. In examples (4\&5), the negative acts of the 'other' are made sever. Some strong nouns (e.g. massacre and terrorist) are used to stress the Other's negative act. This ideological representation serves the favors of the dominant groups.

On the other hand, in Chapel Hill incident, when three Muslims were shot dead by a white American,the negative acts of the in-groups are alleviated and deemphasized in order not to present the "Self" in negative terms. In other instances, the bad qualities of the in-groups are mitigated by the choice of lexis. Moreover, the doer of the negative acts is deleted by using passivization. Besides, the negative acts are sometimes nominalized to shift the attention on the act rather than the actor. The following examples explain this: 
6-Ouederni, vice president of the UNC Muslim Student Association, said relations between Muslims and other Americans in the Raleigh-Durham-Chapel Hill area had been very good. "I don't think it plays a significant part in our relations," he said. "They are not us, and we are not them. We lost Muslims last night, but we also lost three great Americans."(By Kevin Sullivan,Mark Berman and Sarah KaplanFebruary 11，2015， The Washington Post)

7-Three Muslim students dead in North Carolina shooting as suspect arrested (by Dan Roberts, Wed 18 Feb 2015, The Guardian)

8-In Chapel Hill, Suspect's Rage Went Beyond a Parking Dispute (Jonathan M. Katz and Richard PerezPena,March 3, 2015, NYT)

9-In Chapel Hill Shooting of 3 Muslims a Question of Motive (by Jonathan M. Katz and Richard Perez-Pena, Feb. 11, 2015, NYT).

In example (6), the polarization between the "Self" vs. the "Other" is clearly mentioned as "They are not us, and we are not them". This binary opposition indicated by the pronouns "they" vs. "we" and "us" vs. "them" differentiates and 
segregates the "Self" from the "other'. This psychological barrier results in the framing and stereotyping of the "Other" as "terrorists" and "extremists". In example (7), the headline is made passive and the actor of the negative act is hidden. The author's ideology should be questioned here. Because the doer of the negative act belongs to the in-group, his identity is hidden and the sentence is passivized. Similarly, in example (8) the perpetrator's violent act is reduced to "rage". Indeed, the reporter softens the horrible act of the in-group. Likewise, headline (9) nominalizes and foregrounds the act of "shooting" in order to turn the attention away from the doer. Finally, there is a hidden ideology at play in the representation of the "Other" group. The readers should be made aware of its existence.

\section{Results}

Through critically analyzing some editorials in three Western newspapers, The New York Times, The Washington Post, and the Guardian, the researcher has found out that Arabs are represented negatively. The findings of this study are based on the linguistic analysis of some news coverage. The results showed that media often covers news in an ideologically biased way that serves the best interest of the dominant groups and shapes the public opinion. This ideology tends to represent the 'other' group (Islam and Muslims) in an unfavorable way 
through the selection of linguistic choices.Besides, the data analysis revealed that Islam and Muslims are represented negatively. This misrepresentation emphasizes stereotypes and represents Muslims and Islam in an unfavorable way. The image of Muslims as terrorists and security threats is a recurrent them in news reports. Journalists resort to this stereotypical image to account for any future events. Therefore, the image of Muslims as terrorists has been a recurrent cliché for media scrutiny.

\section{Conclusion}

This study attempted to analyze the self/other representation in some Western media by employing Van Dijk's socio-cognitive approach. In this framework, Van Dijk (1998) proposed that the dominant groups emphasize the negative acts of the other groups while deemphasizing the negative acts of the self. Charlie Hebdoattack, which was committed by some Arabs, was described in Western media as "terrorist". On the contrary, the shooting of three Arabs by an American in Chapel Hill incidentwas downplayed in Western Media to merely a "hate crime". Besides, unlike Charlie Hebdo incident, Chapel Hill attack was mitigated and was not given much prominence in the news.The study concluded that there is a hidden ideology in the negative presentation of the other groups. This underlying ideology serves the interests of the dominant groups. 


\section{References}

Chong, D., \&Druckman, J. N. (2007). Framing theory. In Annual Review of Political Science (pp. 103126). (Annual Review of Political Science;Vol.10).DOI:10.1146/annurev.polisci.10.0 72805.103054

Davies, M. (2007). The attraction of opposites: The ideological function of conventional and created oppositions in the construction of in-groups and out-groups in news texts. In L. Jeffries, D. McIntyre \& D. Bousfield (Eds.), Stylistics and social cognition (Vol. 4, pp.71-100). Amsterdam: Editions Rodopi BV.

Eltantawy, M. (2007). U.S. newspaper representation of Muslim and Arab women post 9/11. Dissertation Abstracts International 68: 4904-4905

Irham\&Wahyudi, R. (2012).Treating disclaimers as a power strategy of self-legitimation and other Delegitimation in Netanyahu's UNGA speech. Language Discourse and Society, 2(1)

KhosraviNik, M. (2009).The representation of refugees, asylum seekers and immigrants in British newspapers 
during the Balkan conflict (1999) and the British general election (2005). Discourse and Society, 20 (4), 477-498.

Kuo, S. H. \& Nakamura, M. (2005). Translation or transformation? A case study of language and ideology in the Taiwanese press. Discourse \& Society, 16(3), 393-417.

Merskin, D. (2004). The Construction of Arabs as Enemies: Post-September 11 Discourse of George W. Bush. Mass Communication and Society, 7 (2), 157-175.

Montgomery, M. (2007). The discourse of broadcast news: A linguistic approach. USA \& Canada: Routledge.

Pasha, T. (2011). Islamists in the headlines: Critical discourse analysis of the representation of the Muslim Brotherhood in Egyptian newspapers (Unpublished Doctoral dissertation). University of Utah, USA.

Rashidi, N. \&Souzandehfar, M. (2010). A Critical Discourse Analysis of the Debates Between Republicans and Democrats over the Continuation of War in Iraq. Iran: Shiraz University.

Spillman, K. R., \&Spillmann, K. (1997). Some sociobiological and psychological aspects of "Imagesof the 
Enemy.” In R. Fiebig-von Has \& U. Lehmkuhl (Eds.),Enemy images in American history(pp.4364). Providence, RI: Berghahn

Steuter, E. \& Wills, D. (2009). Discourses of dehumanization: Enemy construction and Canadian media complicity in the framing of the War on Terror. Global Media Journal: Canadian Edition, 2(2), 724.

Van Dijk, T.A. (1985). Thehandbook of discourse analysis. London: Academic Press.

Van Dijk, T.A. (1993a). Elite discourse and racism. Newbury Park, CA: Sage.

Van Dijk, T.A. (1995a). Discourse analysis as ideology analysis.In: C. Schäffner\& A. Wenden (Eds.), Language and Peace. (pp. 17-33). Aldershot:Dartmouth Publishing.

Van Dijk, T.A. (1998). Ideology: A Multidisciplinary Study. London: Sage

Van Dijk, T.A.(2000). Ideology and discourse: A multidisciplinary introduction. Barcelon, PompeuFabra University, 
Van Dijk, T.A. (2002). Political Discourse and Political Cognition, in Paul A. Chilton \& Christina Schäffner (Eds) Politics as Text and Talk. Analytical Approach to Political Discourse. Amsterdam: Benjamins: 204-236 Retrieved from http://www.discourse.org

Van Dijk, T.A. (2003). The discourse and knowledge interface. In: Gilbert Weiss and RuthWodak. (eds.). Critical Discourse Analysis; Theory and Interdisciplinary. 85-109.Palgrave Macmillan.

Van Dijk, T.A.(2004). Poltics, ideogy, and discourse.Retrieved from http://www.discourse-insociefty.org/teun.html.

Van Dijk, T. A., \&Kintsch, W. (1983). Strategies of discourse comprehension. New York: Academic Press.

Wodak, R., \& Van Dijk, T. A. (2000).Racism at the top. Klagenfurt, Austria:Drava. 